Trinity College

Trinity College Digital Repository

Faculty Scholarship

$6-2010$

Melville in the Customhouse Attic

Christopher Hager

Trinity College, christopher.hager@trincoll.edu

Follow this and additional works at: https://digitalrepository.trincoll.edu/facpub

Part of the English Language and Literature Commons 


\section{Christopher Melville in the Customhouse Attic}

Hager

The edifice-originally projected on a scale adapted to the old commercial enterprise of the port, and with an idea of subsequent prosperity destined never to be realizedcontains far more space than its occupants know what to do with.

-Nathaniel Hawthorne, "The Custom-House” (1850)

\section{W}

what to do with their space? In Hawthorne's famous customhouse, some hide away the relics of a prior era where others later discover them and in them glimpse a dark romance of American origins. In the lesser-known customhouse of Herman Melville, the attic harbors no such treasures. It is, like the sarcophagus of the soul, "appallingly vacant as vast," and origins are precisely what is missing. ${ }^{1}$

Melville's fourth novel, Redburn (1849), is the first he began after the largest U.S. territorial acquisition in his lifetime. The conquest of more than half a million square miles from Mexico in 1848, besides appearing to realize the nation's "Manifest Destiny," sparked renewed and intense sectional conflict over slavery. It precipitated the Compromise of 1850, including the nefarious Fugitive Slave Law, and galvanized abolitionism. Even before these prominent effects became clear, Melville's work in the summer of 1849 was already grappling with the basic problem of excess space. The drama of Redburn-a young man's trip across the Atlantic on a merchant vessel, a transit from one customhouse in New York to another in Liverpool-is also the drama of national identity coming to terms with imperial expanse, 
the increasingly global links of U.S. trade, and this spacious, spidery America's cultural estrangement from its geographically localized Revolutionary origins.

From a single striking passage emerges an intricate symbolic order, which this essay will unravel, in which conjoined images of urban space and literary production portray diminished prospects for cultural distinction. Redburn's narrator imagines New Yorkers of a distant future who "may send forth explorers to penetrate into the then obscure and smoky alleys of the Fifth Avenue and Fourteenth-street; and going still farther south, may exhume the present Doric Customhouse, and quote it as a proof that their high and mighty metropolis enjoyed a Hellenic antiquity." ${ }^{2}$ The metaphysics of this prediction are mind bending: lower Manhattan will have been so deeply buried, and with it any trace of the nineteenth century, that New Yorkers will know nothing of their city's past without the aid of archaeology-but their knowledge of ancient Greece somehow will have survived intact. (Readers of a certain temperament will relish imagining the particular cataclysms that could bring this about.) By itself, this jaded remark on delusions of grandeur impugns the very idea that a culture can have an identity apart from mythology. Taken together with a protracted textual archaeology that follows-when Redburn's protagonist explores another city and scrutinizes another customhouse-the New Yorkers' fanciful misapprehension of their past satirizes an antebellum United States that already resembles the aging and decadent empire Melville coyly situates centuries hence. The famous and resilient notion of an exceptional New World republic (descended in various forms from John Winthrop, James Monroe, Ralph Waldo Emerson, John O'Sullivan, and a host of others) held particular sway in 1849. Redburn suggests that this ideology protests too much - not, as in the common critiques, that it sprang from anxiety that the United States remained England's culturally and politically immature offspring, or even that it was simply arrogant and mythological, but rather that Young America exceptionalism worked to conceal that the United States indeed had matured and, in its maturity, resembled England more than ever.

This essay argues for redoubled attention to Redburn and a new perspective on the way Melville's work envisioned antebellum cultural nationalism and geopolitical expansion, as well as their combined impact on the imagination of authorship and selfhood. Both the geographical expanse of the late antebellum United States and the 
layered transformations of urban space encode the contingencies of textual authority in the novel. Scholars have observed Melville's vexed relationship to writing - as both employment and physical practicebut have paid less attention to the political metaphors of that vexation. ${ }^{3}$ In Redburn, the travails of composition and publishing are inextricable from a dour meditation on U.S. empire, American origin, and the individual experience of dislocation. Melville's linked treatments of built environments and textual form-architectures of marble and of prose-serve to scrutinize a society occupying more space than it knows what to do with. ${ }^{4}$

Redburn has always been regarded as a secondary work. Even before it was finished, Melville himself contributed to that assessment, promising his publisher (who was likely alarmed by harsh reviews of the relentlessly allegorical Mardi, just released) that the next book would consist of "no metaphysics, no conic-sections, nothing but cakes \& ale." After Redburn came out, he wrote in his journal, "I, the author, know [it] to be trash, \& wrote it to buy some tobacco with." ${ }^{5}$ Among even those critics who have devoted significant attention to the novel, many explicitly or implicitly assign it merely the instrumental value of illuminating its author and his other achievements. ${ }^{6}$ Heeding Melville's remark that Redburn and White-Jacket were "two jobs, which I have done for money," some readers have regarded Redburn as "an abrupt, perhaps reckless, about-face from the ambitious creative and philosophical course" Melville had begun to chart in Mardi (concluded in 1848 and published in early 1849). ${ }^{7}$ The relatively scarce interpretations of the novel qua novel have treated it as indeed a more straightforward text than Mardi. As a result, the figural intricacies of Redburn have eluded a readership struck mostly by the work's "tough-minded realism," and scholars have not read the novel closely enough to discover how strong Melville's suspicion of cultural nationalism already was in the late $1840 \mathrm{~s}^{8}$

Redburn challenges what we think we know about both Melville's literary practice and his cultural politics in this period. He is too readily regarded as the strident writer who exclaims in Moby-Dick (1851), "Give me a condor's quill! Give me Vesuvius' crater for an inkstand!"; as the cheerleading literary patriot of "Hawthorne and His Mosses" (1850), in which he hails Hawthorne as an American Shakespeare (with 
greater stress on American than on Shakespeare); and as the apparent booster of Manifest Destiny who wrote in White-Jacket (1850):

Long enough have we been skeptics with regard to ourselves, and doubted whether, indeed, the political Messiah had come. But he has come in $u s$, if we would but give utterance to his promptings. And let us always remember that with ourselves, almost for the first time in the history of earth, national selfishness is unbounded philanthropy; for we can not do a good to America but we give alms to the world. ${ }^{9}$

According to a standard narrative of Melville's career, this early fervor yielded-after Moby-Dick's poor reception and the political betrayals of the Compromise of 1850 - to the gathering darkness of Pierre; or, The Ambiguities (1852). The further political turmoil of the 1850s elicited the retrospection of Israel Potter (1855) and the sardonic allegory of The Confidence Man (1857). Later, a witness to the devastation of the Civil War and his own decline as a professional writer, Melville adopted the somber tone of Battle-Pieces (1866) and Billy Budd (1924) and in them evinced great skepticism of state power. ${ }^{10}$

This evolution begins before the writing of these works, I argue, and neither the political events of the early 1850s nor Melville's falling out with the New York literary establishment after Moby-Dick can adequately account for the waning of his Young America nationalism, because both postdate Redburn. ${ }^{11}$ The Melville who wrote the WhiteJacket passage above and the Melville who dismissed his fourth novel as "a beggarly Redburn" were of the same mind-indeed, most of Melville's deprecations of Redburn date to the period when he was finishing White-Jacket-but neither need be taken at his word. ${ }^{12}$ More likely, Melville's famously disparaging comments about Redburn represent a performed apology for the want of national spirit he displayed in that novel; along with them he puts on, like an ill-fitting jacket, the asseverations of national pride in White-Jacket and "Hawthorne and His Mosses." ${ }^{13}$ When he writes in White-Jacket, "Long enough have we been skeptics. . .," Melville may not have referred to collective self-doubt-the "timid, imitative, tame" spirit Emerson disclaims in "The American Scholar." ${ }^{14}$ Rather, he may be confessing with a royal we to the acerbic implications of his previous novel and announcing an effort to overcome his disenchantment. That is to say, the darkness and skepticism associated with Melville's later work were not 
discoveries he made during the writing of Moby-Dick, and neither his publishing troubles nor the Fugitive Slave Act explains them as well as the spatial upheavals of national expansion and urban growth. Melville's residence in a booming New York City and the expansionism of the 1840s-from his brother Gansevoort's involvement in the 1844 Oregon campaign ("Fifty-four Forty or Fight!") to the Mexican Cession of 1848-form the central context for understanding the counternationalist tendencies that emerge in Redburn.

In the novel, Wellingborough Redburn, adolescent child of a father who died in bankruptcy (like Melville's father, Allan), ships aboard a merchant vessel bound for Liverpool. He takes with him a leatherbound volume from the family library - a remnant of their fiscal glory days - called The Picture of Liverpool, a guidebook his father had used on a visit to the city. On his voyage, Redburn studies the book extensively, eagerly preparing to tour the streets he reads about, to see and experience all that his father did. When he gets to Liverpool, though, Redburn finds that the city has changed dramatically in the decades since the book's publication. The narrative of Redburn proceeds to rove through an urban landscape Melville reconstructed half by memory and half by cribbing from the outdated guide. Young Redburn, though he tries doggedly, despairs of discovering through the guidebook's mediation his father's spirit alive in the streets of the city. This sequence has often been taken as a compositional afterthought, the guidebook an expedient means of padding a manuscript Melville was trying feverishly to get to press - and hoped would appear in England in two volumes. Indeed, Melville almost certainly made a second pass through his manuscript after he had already completed the basic narrative of Redburn's sea voyage, inserting several new elements, most notably the guidebook sequence. ${ }^{15}$ The episode is no simple afterthought, however; it represents a remarkable convergence of problems critical to understanding Melville's dark vision of the U.S. political experiment in the wake of 1848 's territorial growth.

Upon his arrival in Liverpool, young Redburn grows starry-eyed sitting alone in a side room at a tavern: "I was now seated upon an English bench, under an English roof, in an English tavern, forming an integral part of the English empire. It was a staggering fact, but none the less true" (133). More than a dozen chapters and several weeks later, one would think no time has passed, or that Liverpool has somehow lost all its Englishness. On a trip out of the city into the country, Redburn 
waxes romantic about "the ale I had drunk:-fine old ale; yes, English ale, ale brewed in England! And I trod English soil; and breathed English air; and every blade of grass was an Englishman born" (21112). Although he already, at that point, has roamed all over Liverpool for weeks on end-has sat upon many an English bench-he insists that this, the more pastoral setting, "was old England, indeed! I had found it at last - there it was in the country!" (209). After all, Liverpool "was very much such a place as New York" (202) ${ }^{16}$ Englishness gets deleted from Redburn's Liverpool and relocated to the countryside, and the process of its deletion is an effect of authorial addition: this seeming contradiction reveals that Melville returned to his finished first draft and expanded it by inserting Redburn's journey through the city-an episode that falls precisely between the two narrative moments I have cited above.

The crux of Redburn's encounter with Liverpool is The Picture of Liverpool, and the guidebook is the governing trope of this pivotal sequence of the novel. It articulates the problems of fluctuating geopolitical identity as the material dynamics of urban space and written composition. As Melville's expansion of his manuscript serves to sap Liverpool of its Englishness, the spatial expansion of the United States dilutes national identity, and this analogy underlies what Melville wrote during the summer of 1849: the additions to Redburn and then White-Jacket. Melville labored that summer under the imperative to crank out novels that might compensate for the poor commercial performance of Mardi, and he particularly wanted a two-volume Redburn to command a higher advance from his British publisher, Richard Bentley. On 5 June 1849, he wrote Bentley that the new novel would be "perhaps a fraction smaller than 'Typee.'” By 20 July, he reported that he was nearly finished and had "enlarged it somewhat to the size of 'Omoo'-perhaps it may be a trifle larger." ${ }^{17}$ Melville's possible discomfort with the artifice of bulking up his novel manifests itself in his textual additions' doubtful representation of national identity in an imperial age..$^{18}$ Instead of frustration about an artistic vision distorted by commercial exigencies (which many readers rightly discern in Pierre), murmured outrage about the distortion of political ideals inflects Redburn's complicated spatial tropes. In its parallel archaeologies of buildings and texts, the guidebook sequence explores the complexities of an anxiety about the U.S. founding that emerged in Mardi in comparatively simplistic form. In that novel, the narrator and 
his band of roving Polynesians sail toward the shore of Vivenza, Melville's stand-in for the United States, and they see overspreading their entry "a lofty natural arch." The resemblance of this natural feature to one in Thomas Jefferson's Notes on the State of Virginia (1781) is no accident, for upon the arch are etched "immense hieroglyphics" that read: "In-this-re-publi-can-land-all-men-are-born-free-and-equal," and in tiny letters below, "Except-the-tribe-of-Hamo."19 The depredation of American founding documents, expressed here simply as the hypocrisy of the asterisk, becomes in Redburn, as we now shall see, a kind of multidimensional entropy-a leaching of meaning by spatial expanse and estrangement from origins. ${ }^{20}$

Redburn draws back the curtain on his scene of writing as he begins to describe The Picture of Liverpool (subtly marking the point at which Melville insinuated himself into his own nearly finished manuscript and began expanding it). He pauses to say, "But let me get it down from its shrine, and paint it, if I may, from the life.... I now linger over the volume, to and fro turning the pages so dear to my boyhood,- the very pages which, years and years ago, my father turned over amid the very scenes that are here described" (143). With methodical attention to detail, Redburn creates a picture of the Picture that lingers a whole paragraph over the appearance of the unopened volume, with its green morocco binding and red patched corners "like little cocked hats" (143). But once Redburn exclaims, "[L]et us open the volume" (143), we find something more complicated than a literary filibuster. In his reverential attitude toward the Picture-a talismanic object, a mystical portal to the past-Redburn construes its text as merely the visible part of its total implied meaning. Noting with admiration that the guidebook's author traces the history of Liverpool all the way back to "a record in the Doomsday-Book of William the Conqueror" (148), Redburn goes on to suggest that a more thoroughgoing report "would have scorned to stop in its researches at the reign of the Norman monarch, but would have pushed on resolutely through the dark ages, up to Moses, the man of Uz, and Adam; and finally established the fact beyond a doubt, that the soil of Liverpool was created with the creation" (148). This playful hyperbole quickly gives way to more straight-faced and menacing remarks about the New York customhouse. This passage situates even a caricature of the quest for storied origins, like the one above, in a larger, more inescapable historical contingency: 
And even as this old guide-book boasts of the, to us, insignificant Liverpool of fifty years ago, the New York guide-books are now vaunting of the magnitude of a town, whose future inhabitants, multitudinous as the pebbles on the beach, and girdled in with high walls and towers, flanking endless avenues of opulence and taste, will regard all our Broadways and Bowerys as but the paltry nucleus to their Nineveh. From far up the Hudson, beyond Harlem River, where the young saplings are now growing, that will overarch their lordly mansions with broad boughs, centuries old; they may send forth explorers to penetrate into the then obscure and smoky alleys of the Fifth Avenue and Fourteenth-street; and going still farther south, may exhume the present Doric Custom-house, and quote it as a proof that their high and mighty metropolis enjoyed a Hellenic antiquity. (149)

The passage begins as a simple (but discerning, especially this early in the industrial age) comment about urban growth; its spectacular pace quickens in turn the rate at which the present seems to become the past. When Jefferson ponders the shelf-life, as it were, of democratic legislation, he posits that every law "naturally expires at the end of 19 years," by which time the living generation overtakes the one that framed the laws; thus, each generation must have its own revolution. ${ }^{21}$ Melville balances the excitement and anxiety of a social revolution - nineteenth-century urbanization - as he writes lavishly of this dreamt-of future New York, but he also zeroes in on an epistemological dilemma. Whereas Jefferson worries that the passage of time will deprive laws of their authority, Melville expects knowledge to lose its reliability. Today's New York guidebooks trumpet a grandeur sure to be surpassed, he points out with perfect reasonableness. What is more surprising is that as the paragraph turns from the perspective of guidebooks to that of human beings themselves-"future inhabitants"-it shifts the locus of misinformation from texts (which obviously can become obsolete) to people (who, we prefer to believe, ride the wave of progress). These individuals' collective self-image loses its grip on reality by the climactic end of Melville's periodic sentence. The passage's wandering rhetoric enhances the effect of reliable knowledge slipping away: the customhouse must be "exhume[d]," but under what is it buried? Smoke and obscurity? It is little wonder, in the end, that Melville's imagined future New Yorkers, consigned to reading the archaeological record beneath a tumultuous landscape's 
occlusions, should fabricate a happy narrative-should strain to find in the evidence of Greek-Revival architecture a coherent narrative of their history. ${ }^{22}$

Melville chose as the artifact with which New Yorkers would delude themselves about their past a building whose very construction forms a study in competing self-definitions on a national stage. The New York customhouse at the time Melville wrote Redburn was a relatively new structure, built in 1842 at Wall and Nassau Streets, the site of the first federal building-Congress's first meeting place, where George Washington took the first presidential oath of office in 1789 and delivered his farewell address in 1796. Today it is the Federal Hall National Memorial, and the National Park Service bills it as "The Birthplace of American Government." ${ }^{23}$ Like another iconic edifice of which Melville took notice - the Bunker Hill Monument, to which he dedicated Israel Potter in 1854-the New York customhouse had been under construction during most of the author's life. Both structures were begun before Melville turned fourteen, and both were still under construction when he shipped out on a whaling vessel in 1841 at age twentyone. By the time he returned to the United States only three years later, both structures were newly finished. (In the Israel Potter dedication, Melville jokes that the eleven-year-old monument at Bunker Hill was "prematurely gray," picking up the thread of Redburn's convolutions about the customhouse's misleading age.) ${ }^{24}$

However much the customhouse afterward came to seem a nationalist emblem, however much its site symbolized the origins of U.S. government, the building itself signified much more equivocally in the 1840s. It was designed by the successful Greek-Revivalist firm of Ithiel Town and Alexander Jackson Davis. ${ }^{25}$ Their original plans, drawn up in 1833, were based on the Athenian Parthenon but featured an exposed dome projecting out of the gabled temple roof. In effect, its designers fused the Parthenon with the Roman Pantheon. (At least one newspaper actually seemed confused: the New Hampshire Sentinel reprinted a notice that the structure "is in imitation of the Pantheon at Athens" and repeatedly made comparisons to "the Panthenon." ${ }^{26}$ ) An 1835 editorial excoriates the dome as "an excrescence, which however elegant in itself, is utterly monstrous and barbarous when added to a model of the purest Grecian architecture." 27 The architectural controversy proved moot when the builders deemed the dome structur- 


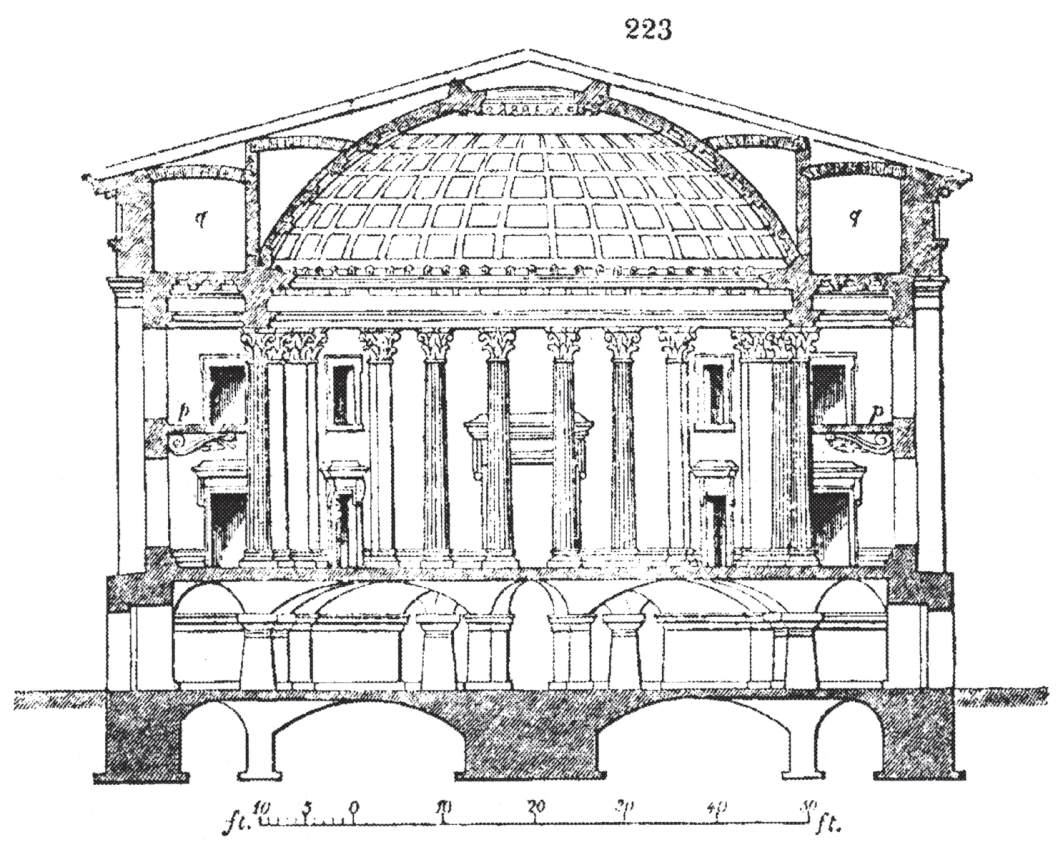

Figure 1 New York Customhouse design from William Ross, "Plan, Elevation, Section, \&c., with a descriptive Account of the Improvements lately made at the Custom-House, New York" (Architectural Magazine 2 [December 1835]: 527.

ally impracticable and retained an English engineer, William Ross, to amend the design - a move that in obvious ways upset the nationalist project of Greek Revivalism. ${ }^{28}$ Ross's revised plan literally internalized the design's aesthetic contradictions: the dome was brought down and secluded within the traditional Doric roof, becoming an interior feature invisible from the outside. This change produced an unencumbered, severe Doric exterior, but it necessitated a substantial reduction in interior size, creating an attic of wasted space between the dome and the roof that encased it (see fig. 1, area marked $q$ ).

As the building neared completion in the early 1840 s, newspaper notices generally lauded the new customhouse. With the dome now discreetly tucked away, no one derided it as an "excrescence." Contemporary observers apparently appreciated the revision that resolved-or, it may be more accurate to say, hid - the building's aesthetic contradictions. The eminent architect Asher Benjamin, a child of the Revolutionary era and a teacher of Ithiel Town, writes: "The 
wants and wishes of the country are expressed in such buildings as Girard College at Philadelphia, the New Custom House at New York, and that at Boston, which do honor to American genius and taste, and will be favorable witnesses, as long as they shall stand, to the degree of present advancement." ${ }^{29}$ For the same reasons other neoclassical architecture proved popular in the young republic, the customhouse's exterior evoked the austerity and political idealism of ancient Greece as an imprimatur for U.S. democracy, and writers such as Benjamin seemed happy to have in the customhouse's uncomplicated exterior an occasion to observe "American genius and taste." Meanwhile, the building's more lavish interior, with its Roman dome and Corinthian columns, suggested a decadent empire. The tension between those two representations was concealed in the hidden space of the attic. ${ }^{30}$

Melville's imagination of New York's "Hellenic" (punningly: Attic) past speaks more to cultural ties with England than with Greece. Architectural historians have argued that the Greek Revival was not the indigenous expression of American independence that many of its promoters claimed. "Taste during these years was a truly international language," writes W. Barksdale Maynard, "and the Greek Revival, far from being an American revolt against British hegemony, was if anything an eager-one could almost say servile-acquiescence to foreign preferences" (249). Maynard insists that the Greek Revival was an aesthetic trend and not a political phenomenon-a matter of "taste"-but transatlantic politics were not far beneath the surface. One of neoclassicism's contemporary critics, architect Edward Shaw, writes in 1844 about a group of flawed neoclassical buildings in which he includes the New York customhouse: "There is nothing, in architecture, worse than tasteless misapplication; it is wearing the secondhand clothes, and not the garb of the ancients; it has the effect of bringing the resources of modern builders into the humiliating position of a kind of architectural Brattle street." ${ }^{11}$ Shaw's allusion seems tautological-Brattle Street is famous principally for the grandiloquent architecture of its houses-unless one concludes that Shaw uses "Brattle street" as shorthand for something else. Before the Revolution, the Cambridge, Massachusetts, street was known as Tory Row, thanks to the concentration of British loyalists who lived there, and colonial Americans appeared to be sensible of the street's political symbolism: Washington garrisoned the houses on Brattle Street in 1775 after their owners fled. Melville, whose familial connection to the American 
Revolution is well known, concludes his short story "The Apple-Tree Table" with a reference to the marks "where the cannon balls struck Brattle street church." ${ }^{2}$

These shadows of England in the cultural politics of antebellum architecture become an unmistakable presence in the case of a customhouse-not just a building, after all, but the visible symbol of international commerce, which, for the United States in the 1840s, consisted overwhelmingly of trade with England. The Walker Tariff of 1846 and Britain's repeal of its Corn Laws combined to usher in an era of unprecedented free trade between the two countries. Even if tariffs had not been one of the enduring political issues of his time, Melville still would have been keenly aware of the politics of transatlantic trade: like Redburn, he shipped aboard a merchant vessel to Liverpool; his father was an importer of goods from Europe; and, more recently, Melville had needed to learn the vagaries of U.S. and British copyright laws. ${ }^{33}$ The New York customhouse becomes more expressly a trope of Anglo-American echoes in the next chapter of Redburn, when the protagonist disembarks and tours Liverpool.

Like the American customhouse-constructed on a site of origin but susceptible to an extravagant misinterpretation of that origin-the Liverpool customhouse proves exceedingly difficult to read. While walking through Liverpool with his guidebook in hand, Redburn determines to visit "The Old Dock":

[I] found myself before a spacious and splendid pile of sculptured brown stone; and entering the porch, perceived from incontrovertible tokens that it must be the Custom-house. After admiring it awhile, I took out my guide-book again; and what was my amazement at discovering that, according to its authority, I was entirely mistaken with regard to this Custom-house; for precisely where I stood, "The Old Dock" must be standing. And reading on concerning it, I met with this very apposite passage:- "The first idea that strikes the stranger in coming to this dock, is the singularity of so great a number of ships afloat in the very heart of the town, without discovering any connection with the sea." (158)

The Picture of Liverpool proves accurate and inaccurate at once: it predicts that Redburn will find a striking "singularity," but not the one 
he actually encounters. Where the guidebook anticipates a conflict in the physical environment-at the same place, a density of ships that denotes sea and a density of buildings that denotes land-Redburn confronts a conflict in his symbolic environment: the "authority" of the guidebook says dock, but some unnamed yet "incontrovertible tokens" (presumably of business activity) say Custom-house. Unlike the geographic singularity the guidebook foretells, this conjunction is less physical than historical; both the dock and the customhouse are sites of commerce, only at different stages of economic development.

When the confused Redburn investigates the matter, he discovers that his quandary is akin to that of Melville's fictive future New Yorkers. He speaks with a police officer who explains, "It seems that in this place originally stood the 'pool,' from which the town borrows a part of its name, and which originally wound round the greater part of the old settlements; that this pool was made into the 'Old Dock,' for the benefit of the shipping; but that, years ago, it had been filled up, and furnished the site for the Custom-house before me" (158). Not only is the customhouse not what the guidebook indicates should be there, but it also specifically conceals the origin of the place's identity: the pool in Liverpool. Like the New York customhouse that stamps Greece upon the site of America's Revolutionary beginnings, this customhouse also stands atop an archaeology of political and cultural origins. Liverpool's entire economic history-from its beginnings to the rise of commercial shipping to the institutionalization of commerce in the customhouse-is expressed in the succeeding incarnations of a single site. Indeed, Redburn's lesson in the history of this space provides what he has previously noted the guidebook could not: a genealogy of Liverpool stretching clear back to the creation.

In this way, Redburn's stroll through Liverpool becomes a supplement to the guidebook itself. It follows the conventions of nineteenthcentury guidebook literature and demonstrates the extent to which that literature shares with civic architecture the project of crafting coherent narratives of collective identity. ${ }^{34}$ Antebellum guidebooks shared such predictable conventions - including an opening historical section explaining a place's origin and the etymology of its name, and accounts of public buildings - that Washington Irving could parody the genre as early as $1809 .{ }^{35}$ Redburn assembles stereotypical guidebook knowledge of Liverpool's origins, but he derives it as much from his own on-the-street research (including his conversation with the police 
officer) as from the book, much as the New Yorkers of the future will (although ineptly) supplement their dated guidebook histories with excavation. Using buildings and books together, Redburn authors an impromptu revised edition of the Picture at the same time that Melville, by narrating Redburn's exploration, enlarges his manuscript.

Any guidebook translates urban space into textual form, but that translation is immanent in the Picture, the narrator would have us believe, even before Melville imports the book into his novel. Like the future New Yorkers' strained reckoning with archaeological evidence, Redburn's aspiration to commune with the spirit of his father relies on a textual archaeology that presents similar interpretive problems. Redburn guides readers through the Picture with as much care as the book should lead visitors through the city; he narrates a physical examination of the book and finds changing practices of reading and writing recorded in it like the inscription of cultural and economic history on an urban landscape. In some of the book's blank spaces, Redburn's father had kept accounts of his finances and schedules of his days during his visit to Liverpool. On a fold-out map, a series of dotted lines in the father's pen "delineate his various excursions in the town" (145). Cross-referencing the dotted lines with the diary entries penciled in the margins, Redburn reconstructs his father's daily journeys and even his father's consciousness at the time; noticing a church marked on the map, Redburn remarks, "I perceive that my father forgot not his religion in a foreign land" (145). The flyleaves of the book are covered in drawings and notations that Redburn himself, with his brothers and sisters and cousins, had made as a child in the paternal home, long after his father's journey. Before he even comes to the title page and begins his report of the book's "original" content, Redburn has depicted a text replete with meanings and functions, written over by the practices of reading. The book that is a Picture has become a guidebook, diary, and ledger, then a playbook for the children, then a metonymic link between child and father, and here it mutates into an appendage of another book, since Redburn will borrow from the Picture throughout several subsequent chapters.

Critics have observed the irony of chapter 30's final paragraph, in which Redburn conjures and then dismisses the temptation to quote passages from the guidebook: "I will not quote thee, old Morocco," cries Redburn, because he deplores the thought that the gloried Pic- 
ture of Liverpool should be "dishonored by shallow-minded readers," and that he "should be charged with swelling out my volume by plagiarizing from a guide-book-the most vulgar and ignominious of thefts!" (150). The irony is not simply that, Redburn's promise notwithstanding, Melville does swell out his volume by plagiarizing from the guidebook (whole chunks and little snippets of information from the Picture crop up in about half a dozen chapters).$^{36}$ Additionally, this outcry against plagiarism comes on the heels of a compelling case against the existence of any textual authority that plagiarism might transgress. The Picture - the one the narrator claims to be holding in hand at the moment of composition - has among its "authors" the person who wrote the published text, the father who kept an impromptu diary of his travels in the book, the siblings and cousins who also marked and drew in it, eight-year-old and thirteen-year-old versions of Redburn himself, an "incorrigible pupil of a writing-master," and a "crayon sketcher of wild animals and falling air-castles" (143). Redburn's archaeological account of the guidebook highlights readership's material traces and literalizes the theoretical proposition that reading constitutes a text's meaning; Melville's representation of Redburn's compositional process suggests that novel's "ignominious ... thefts" are a species in the same textual genus as marginalia. ${ }^{37}$

The limits of the guidebook's authority are unmistakable on two counts. The book has multiple authors, and it conflicts with the "incontrovertible tokens" Redburn discerns in the physical Liverpool. Those limits materialize in subtler fashion, too, as we consider the other resonances of "authority" pertinent to Redburn's story. His troubled relationship to paternal authority echoes the national anxiety that historian George Forgie describes in Patricide and the House Divided. Indeed, paternity and nationhood were exceptionally intertwined in the Melville family. ${ }^{38}$ Moreover, the contingency of the guidebook conjures up the contested nature of the Revolutionary textual foundations of the United States. Redburn may treat the Picture with the sanctity of a communal charter, but Melville most clearly conjures up the ghost of Jefferson by changing the guidebook's date of publication from 1808 to $1803 .{ }^{39}$ The change of date amplifies the guidebook's obsolescence; by situating it just five years earlier, Melville makes the book antedate the abolition of the British slave trade and the Battle of Trafalgar-both monumental events in the life of this port city, both 
alluded to elsewhere in the narrative of Redburn's visit to Liverpool. The new date also marks Jefferson's Louisiana Purchase, the moment at which any guide to U.S. geography had to be most dramatically revised-excepting, of course, the 1848 addition of territory from Mexico that shortly preceded the composition of Redburn. In another notable emendation of the title page, Melville omits the line that billed the guidebook as "A NEW EDITION, CONSIDERABLY ENLARGED"-an unwelcome tell-tale clue, he may have thought, to the textual enlargement in which he was engaged precisely by transcribing this guidebook's title page, even though it was an apt subtitle for the United States in 1803 and in 1849. The transatlantic authorship of The Picture of Liverpool - written by a Briton, written on by Americans-mirrors Redburn itself, thanks to Melville's cribbing the guidebook for his novel. Sydney Smith famously and dismissively asked, "Who reads an American book?" ${ }^{40}$ Not the reader of Redburn, who finds between its covers the mingled words of authors born on the banks of the Hudson and the banks of the Mersey.

Redburn may be disappointed that his dear guidebook is little relevant to a Liverpool now forty years older, but his real trouble turns out to be his inability to locate himself in the larger, newer city. His plight echoes that of the New York customhouse and antebellum U.S. culture: trying to incorporate several temporal dimensions (like a Greek or British past with an Anglo-American present, or a geopolitical David's identity with a Goliath's reality), Redburn finds himself internally in crisis. As the guidebook harbors an unruly multiplicity of textual authorities, Redburn becomes, in this late-stage addition to Melville's novel, a riven and indeterminate self.

The guidebook had served as a prop of identity as well as a consoling reminder of home and family during his transatlantic voyage. He had so "familiarized [him] self with the map" that he "could turn sharp corners on it, with marvelous confidence and celerity" (152). That the city does not match the map is less disarming for Redburn than his failure to navigate space with the same "confidence and celerity" he exhibited as a reader. Before his arrival in England, he follows the dotted lines on his father's map in an imaginary visit to Liverpool; that moment telegraphs the narrative of chapter 31, in which Redburn tries to retrace his father's wanderings in the physical city. Expecting 
that he can inhabit his father's city and his own at once, he anticipates a plenary experience of self. He finds instead scarcity and alienation - a self not fully rooted in any time. When Redburn walks into the Liverpool customhouse, recognizes it as a customhouse, but has it on textual authority that he is not in a customhouse, he finds the entire experience "too confounding altogether" (158). Trying to find some conjunction between his visit and his father's, he muses:

How differently my father must have appeared; perhaps in a blue coat, buff vest, and Hessian boots. And little did he think, that a son of his would ever visit Liverpool as a poor friendless sailor-boy. But I was not born then: no, when he walked this flagging, I was not so much as thought of; I was not included in the census of the universe. My own father did not know me then; and had never seen, or heard, or so much as dreamed of me. And that thought had a touch of sadness to me; for if it had certainly been, that my own parent, at one time, never cast a thought upon me, how might it be with me hereafter? (154)

This reverie of metaphysical dispossession initiates a series of affective oscillations. Repeatedly, Redburn cannot find the Liverpool of the guidebook, laments the book's distance from the present reality, and returns, each time more devotedly, to the guidebook, sole occupant of the vacant space of self-knowledge.

At first, Redburn counters the guidebook's mistakes with palliating interpretations: "I could not, for one small discrepancy, condemn the old family servant" (153); a certain edifice not listed "was but a slight subsequent erection, which ought not to militate against the general character of my friend for comprehensiveness" (155). As the stakes get higher-as Redburn seeks out the hotel where his father stayed, the place from which all the map's dotted lines radiate and from which Redburn plans to "follow him through all the town" (154) - the city's rebuffs grow more forceful. When he cannot find the hotel at the place to which the guidebook directs him, Redburn seeks counsel but has "a dignified looking personage" slam a door in his face. The "gentlemen and ladies" of whom he inquires "only stared and passed on" (156). Finally a mechanic informs him that the hotel was demolished long ago, and Redburn's faith in the text suffers its greatest blow: "It was nearly half a century behind the age! and no more fit to guide me about the town, than the map of Pompeii... [T] his precious book was next to 
useless. Yes, the thing that had guided the father, could not guide the son" (157). After a paragraph-long dark night of the soul, Redburn at last resolves, "No. - Poor old guide-book, thought I, tenderly stroking its back, and smoothing the dog-ears with reverence; I will not use you with despite, old Morocco! and you will yet prove a trusty conductor through many old streets in the old parts of this town" (157). But again he discovers an error, and thinks he will "put the book into [his] pocket, and carry it home to the Society of Antiquaries"; he decides the useless book must be older than the Pentateuch. Again he relents, and again "rub[s] its back softly, and gently adjust[s] a loose leaf: No, no, I'll not give you up yet” (159).

The discrepancies become more numerous and the reconciliations more strained, and Redburn reflects that at day's end he has seen nothing of England at all, none of its fabled past. He has seen only the new, unmapped edifices of Liverpool: "Is there nothing in all the British empire but these smoky ranges of old shops and warehouses?" (159). Liverpool is not his father's England, nor does it seem to be England at all. One of Redburn's most memorable observations of Liverpool is that it "was very much such a place as New York" (202). He does not conclude that the differences between the two nations might be less than he has imagined, nor does he blame the guidebook for failing to reveal the romantic antiquity that has lured him across the ocean. Instead, he "remonstrate[s]" with himself: "[Y] ou are but a sailor-boy, and you can not expect to be a great tourist, and visit the antiquities, in that preposterous shooting-jacket of yours. Indeed, you can not, my boy" (159). No longer apostrophizing the guidebook in the name of its old Morocco garb, Redburn has found the source of his trouble inside his own jacket.

What is the relationship of individual disorientation to upheavals on the scale of national geography and culture? How are imperial vastness and the distance of origins felt privately? Redburn raises these questions but cannot wrestle with them because they emerge only in a hasty augmentation of a manuscript that was already mostly finished. When the novel turns away from the guidebook sequence (to the Harry Bolton episode, also a late addition, and the return voyage to New York, which Melville evidently preserved intact from the first manuscript), the rising conflict of Redburn's relationship to father, past, and nation simply disappears - because although readers have not, at this point, reached the end of the novel, they have reached 
nearly the latest date of Melville's composition. Fluid national identities, American and British; dynamic built environments; and contested textual authorities have accumulated in a succession of spaces both real and symbolic, and they wind up inside Redburn's jacket, his desperate bulwark against the cognitive drift endemic to passing time and spatial expanse.

If we think about the guidebook sequence not as the middle part of Redburn, as it is in published form, but rather as one of the last parts of the novel that Melville wrote, we begin to discern its continuity with what Melville wrote next: not the rest of Redburn but a new novel that, perhaps not coincidentally, features a protagonist identified by his jacket. Melville finished Redburn around the end of June 1849that is, finished his late-stage augmentations, including the guidebook sequence - and evidently began writing White-Jacket immediately, finishing it in less than two months. Out of the unresolved quandary of Redburn, its protagonist's disorientation amid the expanse and novelty of the imperial nation, comes the narrative of an individual marginalized by his jacket and entailed within the ambient force of the nationstate's martial arm.

Redburn's vexed relationship with his guidebook evokes the author's own attitude toward his novel, and in this light Melville's deprecating remarks about Redburn reveal a more complicated tension than that between artistic ambition and financial reward. His will to expand the manuscript registers as a reaction to U.S. cultural politics as strongly as it does an economic action. On 3 March 1849, about a month before Melville began Redburn, he wrote a now-famous letter to the editor Evert Duyckinck, in which his impassioned commentaries on Emerson and Shakespeare swell to a climax when he proclaims, "But the Declaration of Independence makes a difference." The tenor of this oblique yet pointed remark seems to be that, whereas Shakespeare labored under "the muzzle which all men wore on their souls in the Elizebethan [sic] day," American writers enjoy greater latitude to "dive" after the truth. As soon as Melville invokes the Declaration he apparently realizes he has little room left on the page- "There, I have driven my horse so hard that I have made my inn before sundown"and he discontinues his meditation on American writers to allow room for one last remark. "You complain that Emerson ... is above munch- 
ing a plain cake in company of jolly fellows, \& swiging [sic] off his ale like you \& me," Melville writes, and he closes by declaring his own ever-readiness to share "a draught of ale or a mouthful of cake." ${ }^{11}$ In the inadvertent narrative of this letter, the spatial confines of the expiring page provoke the roots of the very phrase- "nothing but cakes \& ale"-that Melville would use three months later to describe the novel he strove to swell beyond the covers of a single volume. The cakesand-ale letter, the one more explicitly about Redburn, was written in early June 1849, only a few weeks before Melville finished the novel and probably around the time he augmented his manuscript with the guidebook chapters. If that novel, and particularly its expansion, consists of "cakes \& ale," then by the logic of Melville's three-monthsearlier letter it also constitutes another of his several challenges to Emerson. The call for the American scholar is difficult to heed when the post-1848 United States lacks a reliable guidebook; when the path to its origins at the Declaration of Independence is as hard to retrace as Redburn's father's steps; when America, as it expanded to the Pacific, was shrinking its customhouse's attic.

Trinity College

\section{Notes}

For their helpful comments on drafts of this essay, I am grateful to Marcy Dinius, Jay Grossman, Paul Lauter, Louis Masur, David Rosen, and Julia Stern.

1 Nathaniel Hawthorne, The Scarlet Letter, vol. 1 of The Centenary Edition of the Works of Nathaniel Hawthorne, ed. William Charvat et al. (Columbus: Ohio State Univ. Press, 1962), 28. Herman Melville, Pierre; or, The Ambiguities, vol. 7 of The Writings of Herman Melville, ed. Harrison Hayford, Hershel Parker, and G. Thomas Tanselle (Evanston and Chicago: Northwestern Univ. Press and the Newberry Library, 1971), 285.

2 Herman Melville, Redburn: His First Voyage, Being the Sailor-Boy Confessions and Reminiscences of the Son-of-a-Gentleman, in the Merchant Service, vol. 4 of The Writings of Herman Melville, ed. Harrison Hayford, Hershel Parker, and G. Thomas Tanselle (Evanston and Chicago: Northwestern Univ. Press and the Newberry Library, 1969), 149. Further references to Redburn are to this edition and will be cited parenthetically in the text.

3 On Melville and the publishing marketplace, see, among others, William Charvat, The Profession of Authorship in America, 1800-1870 (1968; reprint, New York: Columbia Univ. Press, 1992); and Ann Douglas, The 
Feminization of American Culture (New York: Knopf, 1977). On Melville's troubled relationship with the written page, see Elizabeth Renker, Strike through the Mask: Herman Melville and the Scene of Writing (Baltimore: Johns Hopkins Univ. Press, 1996).

4 This essay is much indebted to Anne Baker's recent book, which argues that territorial growth in the antebellum United States incited as much cultural anxiety as expansionist fervor (Heartless Immensity: Literature, Culture, and Geography in Antebellum America [Ann Arbor: Univ. of Michigan Press, 2006]). Baker helpfully complicates a common critical view of Melville as a participant in the antebellum period's individualist-imperial logic; she reveals important ways in which Moby-Dick worries about that mood, specifically its incarnation in the geographical expansion of the United States. The present study differs from Baker's in that, while I do take geographical space as a starting point, my analysis of Redburn has less to do with cultural anxieties about geographical expanse than with Melville's spatial tropes and textual practices as responses to territorial growth.

5 Herman Melville to Richard Bentley, 5 June 1849, in Correspondence, vol. 14 of The Writings of Herman Melville, ed. Harrison Hayford, Hershel Parker, and G. Thomas Tanselle (Evanston and Chicago: Northwestern Univ. Press and the Newberry Library, 1993), 132; and Herman Melville, Journals, vol. 15 of The Writings of Herman Melville, ed. Harrison Hayford, Hershel Parker, and G. Thomas Tanselle (Evanston and Chicago: Northwestern Univ. Press and the Newberry Library, 1989), 13.

6 Scholars of the "Melville Revival" primarily attend to Redburn only to reconstruct Melville's adolescence from it (his protagonist's voyage is based on one he took in 1839, before his more famous Pacific travels). William H. Gilman demonstrates the substantial extent to which Melville had played fast and loose with his experiences aboard a merchant ship to Liverpool when he invented a parallel voyage for Wellingborough Redburn (Melville's Early Life and “Redburn," New York: New York Univ. Press, 1951). Willard Thorp reveals that Redburn provides additional evidence of Melville's frequent reliance on source texts ("Redburn's Prosy Old Guidebook,” PMLA 53 [December 1938]: 1146-56). Throughout the second half of the twentieth century, scholars have searched Redburn for the seeds of Melville's later brilliance. In a 1951 essay, for example, John J. Gross dubs it "The Rehearsal of Ishmael” ("The Rehearsal of Ishmael: Melville's Red-burn,” Virginia Quarterly Review 27 [fall 1951]: 581-600); more recently, Steven Olsen-Smith interprets it as "a textual area of incubation for major themes in Moby-Dick" ("Redburn's 'Prosy Old Guidebook’ Revisited,” Melville Society Extracts 127 [July 2004]: 12).

7 Melville to Lemuel Shaw, 6 October 1849, in Correspondence, 138; Wilson Heflin, "Redburn and White-Jacket," in A Companion to Melville Studies, ed. John Bryant (Westport, Conn.: Greenwood Press, 1986), 145. 
8 James Schroeter, "Redburn and the Failure of Mythic Criticism," American Literature 39 (November 1967): 292. A notable exception is Carolyn L. Karcher, who examines Redburn as an "allegorical exposé of slavery" in which Melville uses the brutalities of "sailor life to dramatize the way slavery violates the manhood of the slave and the humanity of the master." But this view, which reads a form of injustice encoded not in another form but in a merely displaced arena, still treats Redburn as a relatively transparent text (Shadow over the Promised Land: Slavery, Race, and Violence in Melville's America [Baton Rouge: Louisiana State Univ. Press, 1980], 34-35). Among the most interesting and least dated studies of Redburn are sections of Stephen David Rachman, "Reading Cities: Devotional Seeing in the Nineteenth Century," American Literary History 9 (winter 1997): 653-75; Wyn Kelley, Melville's City: Literary and Urban Form in Nineteenth-Century New York (New York: Cambridge Univ. Press, 1996), 116-35, which discusses some of the same elements of the novel on which I focus - the New York customhouse passage and Redburn's disorienting walk through Liverpool-but reads these for their relationship to historical attitudes about the metropolis, not for their metaphorical implications; and, most recently, Elisa Tamarkin, "The Ethics of Impertinence: Douglass and Melville on England,” in Frederick Douglass and Herman Melville: Essays in Relation, ed. Robert S. Levine and Samuel Otter (Chapel Hill: Univ. of North Carolina Press, 2008), 181-206.

9 Herman Melville, Moby-Dick, or, The Whale, vol. 6 of The Writings of Herman Melville, ed. Harrison Hayford, Hershel Parker, and G. Thomas Tanselle (Evanston and Chicago: Northwestern Univ. Press and the Newberry Library, 1988), 456; "Hawthorne and His Mosses," in The Piazza Tales and Other Prose Pieces, 1839-1860, vol. 9 of The Writings of Herman Melville, ed. Harrison Hayford, Alma A. MacDougall, G. Thomas Tanselle, et al. (Evanston and Chicago: Northwestern Univ. Press and the Newberry Library, 1987), 239-53; White-Jacket, or The World in a Manof-War, vol. 5 of The Writings of Herman Melville, ed. Harrison Hayford, Hershel Parker, and G. Thomas Tanselle (Evanston and Chicago: Northwestern Univ. Press and the Newberry Library, 1970), 151. Many critics have discussed the White-Jacket passage, but most have been transfixed by its comparison (explicit in a portion I did not quote) of Americans with the chosen people of Israel. Sacvan Bercovitch calls "the reconciliation of national interest and international beneficence" as expressed in the passage "a cliché of the times" (The American Jeremiad [Madison: Univ. of Wisconsin Press, 1978], 202).

10 On Melville's response to the Compromise of 1850, see, for example, Nicola Nixon, "Compromising Politics and Herman Melville's Pierre," American Literature 69 (December 1997): 719-41. Michael Paul Rogin reads Israel Potter as an outbreak of "Melville's iconoclasm against the Revolution" (Subversive Genealogy: The Politics and Art of Herman Mel- 
ville [New York: Knopf, 1983], 229). Carolyn L. Karcher writes, "By the time he wrote Israel Potter, the hope he had cherished in Moby-Dickthat his compatriots would find a 'prudent' way out of their dilemma by embracing blacks as equal partners in America's destiny-had clearly failed him" (Shadow over the Promised Land, 106).

11 On Melville's relationship to Young America, see Edward L. Widmer, Young America: The Flowering of Democracy in New York City (New York: Oxford Univ. Press, 1999), esp. 93-124. Widmer acknowledges that Melville exhibited some ambivalence about Young American rhetoric as early as Mardi (88-89), but he attributes Melville's ultimate and most complete estrangement from Young America politics in the early 1850s to Evert Duyckinck's unenthusiastic reception of Moby-Dick (116). On Melville's brother Gansevoort's role in the Democratic Party and Young America, see Andrew Delbanco, Melville: His World and Work (New York: Knopf, 2005), 66-67.

12 Melville distanced himself somewhat from White Jacket, too, but Redburn comes in for greater insult, almost exclusively during the fall of 1849 , after he had sent White-Jacket to his publishers. He calls Redburn "a little nursery tale of mine" in a letter to Richard Henry Dana on 6 October 1849, and on the same day writes to Lemuel Shaw, "For Redburn I anticipate no particular reception of any kind" (Correspondence, 141, 138). He refers to the book as "a beggarly 'Redburn'” in a letter to Duyckinck on 14 December 1849 (Correspondence, 149). The journal entry, previously cited, in which Melville claims he "wrote it to buy some tobacco with," is dated 6 November 1849.

13 White-Jacket, of course, is hardly an uncritically nationalist book. Its most famous aspect is a scathing critique of the U.S. Navy's practice of disciplining sailors by flogging - a critique with obvious antislavery resonances. But this very topical condemnation does not attack U.S. nationalism at as fundamental a level as Redburn does in my analysis below. By suggesting that White-Jacket harbors an expression of remorse for the harsh criticisms Redburn levels, I am taking some inspiration from Barbara Foley's compelling interpretation of "Bartleby, the Scrivener" as "an expression of Melville's inchoate and largely unacknowledged regret” for his ancillary role in the Astor Place riots, which, incidentally, took place while he was writing Redburn ("From Wall Street to Astor Place: Historicizing Melville's 'Bartleby,” American Literature 72 [March 2000]: 109).

14 Nature, Addresses, and Lectures, vol. 1 of The Collected Works of Ralph Waldo Emerson, ed. Robert E. Spiller and Alfred R. Ferguson (Cambridge: Belknap Press of Harvard Univ. Press, 1971), 69.

15 See Hershel Parker, "Historical Note," in Redburn, 319, 330-31; Stephen Mathewson, “To Tell over Again the Story Just Told': The Composition of Melville's Redburn,” ESQ 37, no. 4 (1991): 311-20; and Hershel Parker, Herman Melville: A Biography, 2 vols. (Baltimore: Johns Hopkins 
Univ. Press, 1996), 1:640-42. In the latter source, Parker intimates that Melville "plunder[ed]" the guidebook during the first phase of composition, but Parker admits he is offering only his "best guess" $(640,642)$. Mathewson's more detailed analysis corroborates my own conviction, based on the text's internal evidence, that Melville composed most of the guidebook section after he completed the narrative and undertook to "enlarge" it.

16 Elisa Tamarkin's recent book explores the cultural meaning of "England" in the antebellum United States (Anglophilia: Deference, Devotion, and Antebellum America [Chicago: Univ. of Chicago Press, 2008]). Her argument that the American image of England is ultimately less about England than it is "an expression of the anxieties and wishes of someplace else" usefully explains Redburn's relationship to England in the novel (xxiv). Tamarkin discusses the seemingly paradoxical combination of Anglophilia with idolatry of the American revolutionaries (58-76) - a paradox in which Redburn is caught, I would suggest. Tamarkin does not discuss Redburn in Anglophilia, but see "The Ethics of Impertinence," cited above. See also Leonard Tennenhouse, The Importance of Feeling English: American Literature and the British Diaspora, 1750-1850 (Princeton, N.J.: Princeton Univ. Press, 2007); Paul Giles, “'Bewildering Intertanglement': Melville's Engagement with British Culture,” in The Cambridge Companion to Herman Melville, ed. Robert S. Levine (New York: Cambridge Univ. Press, 1998), 224-49; and Marvin Fisher, "The American Character, the American Imagination, and the Test of International Travel in Redburn," in Melville "Among the Nations": Proceedings of an International Conference Volos, Greece, July 2-6, 1997, ed. Sanford E. Marovitz and A. C. Christodoulou (Kent, Ohio: Kent State Univ. Press, 2001), 49-60.

17 Melville to Richard Bentley, 20 July 1849, Correspondence, 132, 134.

18 Renker also argues that Melville's work bears the imprint of his anxieties about his extensive reliance on source texts. She finds such anxieties principally in representations of writing, such as the fearful depiction of the tattooist in Typee (Strike through the Mask, 1-23).

19 Thomas Jefferson: Writings, ed. Merrill D. Peterson (New York: Library of America, 1984), 148; Herman Melville, Mardi, and A Voyage Thither, vol. 3 of The Writings of Herman Melville, ed. Harrison Hayford, Hershel Parker, and G. Thomas Tanselle (Evanston and Chicago: Northwestern Univ. Press and the Newberry Library, 1970), 512-13. Mardi's caricature of Polynesian language involves frequent "o" sounds added to the ends of English words; the descendants of Ham (Africans) become the "tribe of Hamo."

20 Rachman notes "the capacity of urban experience, à la Rip Van Winkle, to create temporal and spatial dislocation" ("Reading Cities," 663); my concern here, following from that observation, is to understand what temporal and spatial dislocation create (or undo). Thomas M. Allen's recent 
book makes an interesting companion to Baker's analysis of spatial imagination in Heartless Immensity (A Republic in Time: Temporality and Social Imagination in Nineteenth-Century America [Chapel Hill: Univ. of North Carolina Press, 2008]). An influential and controversial intellectual history by Major L. Wilson has argued that the Democratic Party's political imagination gravitated around expansion through geographical space and the Whigs' around progress through time (Space, Time, and Freedom: The Quest for Nationality and the Irrepressible Conflict, 1815-1861 [Westport, Conn.: Greenwood Press, 1974]). If we accept Wilson's framework, then Melville's anxieties about vast expanses represent another way in which his late-1840s work is a sort of apostasy from the Young America movement, Manifest Destiny, and his brother Gansevoort and the Democrats. Trish Loughran considers "the many ways in which the nation as a form relies upon the dislocations of its subjects from the scene of their origins" (The Republic in Print: Print Culture in the Age of U.S. Nation Building, 1770-1870 [New York: Columbia Univ. Press, 2007], 439).

21 Thomas Jefferson to James Madison, 6 September 1789, Writings, 963. In our own moment of technological rather than political revolution, the time of Moore's Law, we have come to expect the obsolescence of everything electronic in an even shorter time.

22 Think, here, of the standard creationist's argument that six thousand years ago God made million-year-old fossils. The most postmodern argument a creationist ever willingly makes, it assumes that structures of chronology are relative, contingent on our fundamentally subjective perception-our tendency to see the passage of time in objects and phenomena that exist for us only at the single moment of our looking.

23 National Park Service, "Federal Hall," www.nps.gov/feha (accessed 4 December 2009).

24 Herman Melville, Israel Potter: His Fifty Years of Exile, vol. 8 of The Writings of Herman Melville, ed. Harrison Hayford, Hershel Parker, G. Thomas Tanselle et al. (Evanston and Chicago: Northwestern Univ. Press and the Newberry Library, 1982), vii. Affinities between Redburn and Israel Potter merit further attention. In addition to Redburn's oblique engagement with England and the American Revolution, which I have begun to demonstrate here, the novel may also share a source with Melville's reworking of a Revolutionary veteran's life story (including a sojourn to England). At least one scholar has suggested that Melville acquired Henry Trumbull's 1824 The Life and Adventures of Israel Potter-the principal foundation for Israel Potter-around the time he was writing Redburn and "may have drawn upon the poverty sections" of Trumbull's book for parts of Redburn's visit to Liverpool. See Walker Cowen, "Melville's 'Discoveries': A Dialogue of the Mind with Itself," in The Recognition of Herman Melville: Selected Criticism since 1846, ed. Hershel Parker (Ann Arbor: Univ. of Michigan Press, 1967), 334. 
25 For the history of the New York customhouse, see Roger Hale Newton, Town and Davis, Architects: Pioneers in American Revivalist Architecture, 1812-1870, Including a Glimpse of Their Times and Their Contemporaries (New York: Columbia Univ. Press, 1942), 172; Nichols' Illustrated New York: A Series of Views of the Empire City and Its Environs (New York: C. B. and F. B. Nichols, 1847); and Louis Torres, "Samuel Thomson and the Old Custom House," Journal of the Society of Architectural Historians 20 (December 1961): 185-90.

26 New Hampshire Sentinel 43 (7 April 1841): 2.

27 “Miscellaneous Notices,” American Monthly Magazine 5 (April 1835): 160; quoted in Marcus Whiffen and Frederick Koeper, American Architecture, 1607-1976 (Cambridge: MIT Press, 1981), 156.

28 On neoclassical architecture and antebellum nationalism, see W. Barksdale Maynard, Architecture in the United States, 1800-1850 (New Haven: Yale Univ. Press, 2002), esp. 219-79; and Gwendolyn Wright, Building the Dream: A Social History of Housing in America (Cambridge: MIT Press, 1983), esp. 21-89. William Ross's involvement in the revision of the New York customhouse design is described in William Ross, "Plan, Elevation, Section, \&c., with a descriptive Account of the Improvements lately made at the Custom-House, New York" (Architectural Magazine 2 [December 1835]: 525-33).

29 Asher Benjamin, "Arts of Design in America," North American Review 52 (April 1841): 317.

30 This tension has not eluded twentieth-century critics. Two major works of architectural history published during the 1940s single out this flaw of the New York customhouse. Talbot Hamlin deems the building "a conception lacking in unity." He continues, "The exterior is one thing and the interior another" (Greek Revival Architecture in America: Being an Account of Important Trends in American Architecture and American Life prior to the War between the States [Oxford, Eng.: Oxford Univ. Press, 1944], 154). Newton's history of Town and Davis also decries William Ross's shrunken, internalized dome: "The building thus became a mere caricature of its intended self. Robbed of the deep, rhythmic shadows, it lost a sense of mystery and became just another revivalist building, albeit an impressive one" (Town and Davis, Architects, 172).

31 Edward Shaw, "Architecture in the United States," North American Review 58 (April 1844): 449. Shaw in effect distinguishes the mere aping of classical models from emulation-a watchword of early American culture. See William Huntting Howell, "Spirits of Emulation: Readers, Samplers, and the Republican Girl, 1787-1810," American Literature 81 (September 2009): 497-526.

32 Melville, The Piazza Tales, 397.

33 Indeed, Melville's quip that he wrote Redburn "to buy some tobacco with" seems a less casual remark in light of Redburn's very first experience 
in England: "As soon as we came to anchor in the river, before reaching the dock, three Custom-house underlings boarded us, and coming down into the forecastle, ordered the men to produce all the tobacco they had. Accordingly several pounds were brought forth" (196). For Melville to call Redburn a commodity exchangeable for tobacco may be less dismissive than scholars generally think; it may signal Melville's attentiveness to the book's thematic engagement with Anglo-American relations. On international copyright see Widmer, Young America, 99, as well as Meredith McGill, American Literature and the Culture of Reprinting, 1834-1853 (Philadelphia: Univ. of Pennsylvania Press, 2003).

34 Tellingly, Alexander J. Davis, one of the original designers of the New York customhouse, also drew several of the plates for The Picture of NewYork, and Stranger's Guide through the Commercial Emporium of the United States (New York: A. T. Goodrich, 1818), a much-reprinted guidebook that is the partial basis for my characterizations of guidebook conventions. Melville, incidentally, was at least casually acquainted with Davis; see Wayne Andrews, American Gothic: Its Origins, Its Trials, Its Triumphs (New York: Vintage, 1975), 45.

35 Melville probably read Irving's popular Knickerbocker's History in the spring of 1847 (it was borrowed from the Boston Athenaeum on the account of Lemuel Shaw, Melville's father-in-law, the day Melville arrived for a visit; see Merton M. Sealts Jr., Melville's Reading [Columbia: Univ. of South Carolina Press, 1988], 189). He could have derived just from its title page the conceit of a guidebook history that stretches back to creation-Irving called his work A History of New York, from the Beginning of the World to the End of the Dutch Dynasty, and it indeed begins with a chapter on the "Creation of the World." Melville might well have lingered over this passage on the origin of the name New Amsterdam: "[I]t was considered an excellent and praiseworthy measure to name it after a great city of the old world; as by that means it was induced to emulate the greatness and renown of its namesake-in the manner that little sniveling urchins are called after great statesmen, saints, and worthies, and renowned generals of yore, upon which they all industriously copy their examples, and come to be very mighty men in their day and generation" (Washington Irving, A History of New York, 3rd ed. [Philadelphia: M. Thomas, 1819], 142). Melville's New York customhouse passage shares this impulse to puncture the puffery of New Yorkers' self-image, and his ostentatiously named protagonist, the poor son of a more distinguished Wellingborough Redburn, recalls Irving's urchin. Such affinities in the two texts offer another way in which "Hawthorne and His Mosses," as I suggested earlier, seems a strained falling-in-line with literary Young America. Melville's thinly veiled assault on Irving in that essay ("that graceful writer, who perhaps of all Americans has received the most plaudits from his own country for his productions" [247]) faults him above 
all for a lack of originality and a failure to deviate from English models. Given that Melville in the guidebook sequence of Redburn not only copies from an English guidebook (as he relied on published sources in much of his writing) but also draws some inspiration from Irving himself, it is difficult to believe that Melville's remarks on Irving's unoriginality were entirely unqualified in his own mind. Parker notes certain similarities between Redburn and Irving's The Sketch Book in A Biography, 1:640.

36 Thorp elucidates, passage by passage, Melville's extensive reliance on The Picture of Liverpool in the composition of Redburn ("Redburn's Prosy Old Guidebook").

37 If Melville possessed a copy of The Picture of Liverpool, it has not survived. Although the marginalia Melville imagined for Redburn's copy of the Picture may be unusually fanciful, it was not uncommon for a whole family of early American readers to fill a prized book with loving inscriptions, as Cathy N. Davidson has demonstrated in her study of copies of Charlotte Temple. Indeed, this passage of Redburn keenly anticipates Davidson's claim that "the full text of the early American novel does not end with its printed word but is extended into the scribblings and the lives of its earliest readers" (Revolution and the Word: The Rise of the Novel in America, expanded ed. [New York: Oxford Univ. Press, 2004], 144).

38 George B. Forgie, Patricide in the House Divided: A Psychological Interpretation of Lincoln and His Age (New York: Norton, 1979).

39 See Thorp for a facsimile of the title page of The Picture of Liverpool ("Redburn's Prosy Old Guidebook"); Melville reproduces the text of this page with only slight emendations, including the date, in Redburn, 146.

40 Sydney Smith, review of Statistical Annals of the United States of America by Adam Seybert, Edinburgh Review 33 (1820): 79.

41 Melville, Correspondence, 122. 